\title{
Social Justice and Social Justice Leadership in Higher Education Institutions: The Perception of Women and Persons with Disabilities
}

\author{
Matebe Tafere Gedifew ${ }^{1}$, Girma Shimelis Muluneh ${ }^{1} \&$ Fentahun Mengistu Bitew ${ }^{1}$ \\ ${ }^{1}$ Bahir Dar University, Ethiopia \\ Correspondence: Girma Shimelis Muluneh, Bahir Dar University, Ethiopia. E-mail: girmashimelis@gmail.com
}

Received: August 21, 2019

Accepted: September 18, 2019 Online Published: October 31, 2019

doi:10.5539/par.v8n2p63

URL: http://dx.doi.org/10.5539/par.v8n2p63

\begin{abstract}
This qualitative research aimed at exploring prevailing scenarios related to social justice and social justice leadership as perceived by women and individuals with disabilities. To conduct the study, interpretive phenomenological research method was employed. In doing so, ten participants, including women and people with disabilities were selected using purposive sampling technique. Data were also collected via semi-structured interviews and focus-group discussions. Thus, the research result indicated that participants were not so strange for the concepts related to social justice and social justice leadership albeit their understanding differed. Moreover, participants pointed out that community perception towards women and persons with disabilities are not so fair and progressive, and tailored policies and strategies are not made available and being implemented in the study context. It was also indicated that different forms of sexual harassments, classroom buildings, toilets, shower rooms, dining rooms and distances between classrooms and dormitories were enumerated as major inconveniences and reflection of injustices encountering women and people with disabilities in the study context. On top of this, unfair and unjust practices in areas of staff recruitment and promotion in the study context were major challenges identified in this research.
\end{abstract}

Keywords: social justice, social justice leadership, disability

\section{Introduction}

Social justice has moral, religious, philosophical, and political origins (Coninck, Culp, \& Taylor, 2013). It is understood in a variety of ways. Issues such as fairness, equality, justice, human rights, social benefit, freedom from discrimination and equitable distribution of resources are among words and/or phrases we use to elaborate social justice (Bates, 2007, Sturman, 1997). Mostly, social justice is equated with the notion of equality or equal opportunity in a society. Although equality is undeniably part of social justice, the meaning of social justice is actually much broader (Scherlen and Robinson, 2008). It has a vision of a future and more inclusive society in which the basic needs of all people are met. According to Cribb and Gewirtz (2003), social justice emphasizes on three major elements: a sense of distributive justice (focused on the allocation of resources), associational justice (focused on the distribution of power) and cultural justice (the need to reflect on a broad range of identities).

However, across the world, there are thousands of social injustices expressed in the form of oppression, discrimination, harassment or other forms of inequalities. In line to this, many writers and advocators of the interpretive paradigm pronounce that in several occasions existing laws, theories and social practices do not reflect social justice in a way to fit the marginalized or vulnerable groups in the society (Creswell, 2013),rather, they are meant to serve the powerful and dominant groups. Unfortunately, the oppressed and marginalized groups internalize the image given by the oppressors and adopt the oppressor's guidelines as Paulo Freire (1979) contended. In order to reverse the situation, efforts should be made by all community members. As a result, the questions related to inequality, empowerment, oppression, domination, suppression and alienation will get pertinent and timely answers (Hammersley, n.d.; Mackenzie \& Knipe, 2006). On top of this, Bogotch (2014) explained that the injustices that people experience in their lives cannot only be addressed but also get resolved by the leadership through political, economic and social means. Thus, social leadership is among the major areas that people need to work on in order to make sure that social justice amongst all groups of the community are being applied (Grogan, 2004).

Therefore, beyond acknowledging the prevalence of various types of social injustices, social justice leadership is required to root out those distorted mental models and socially unjust practices often anchored and embedded in 
economic and political dynamics in the community (Bogotch, 2014). According to social leadership approach, issues of equity or fairness, equality of opportunities, respect for differences and diversity, civic responsibility, the advancement of knowledge and personal freedom are significant components that need to be addressed to people (Shields, 2004). Hence, the prime focus of social justice leadership is to bring about justice and equal treatment of people despite differences in gender, language, beliefs, political as well as economic backgrounds exhibited in their day to day lives. Besides, social justice leadership tries to see all societal issues through the lens of equity and it is an antithesis of inequality or injustice, discriminations, stereotyping, and other sorts of inhumane and pathologizing practices.

By the same token, social justice leadership is required and should be exercised by educational institutions as they directly involve and reflect the social, political, cultural and economic practices of the society. However, critical theory strongly criticizes educational leadership as it pays much attention to the educational ideas, policies, and practices that serve the interests of the dominant class while simultaneously silencing and dehumanizing "others" (Brown, 2008). Thus, it is crucial to address issues of power and privilege to weave social justice into the fabric of educational leadership curriculum, pedagogy, programs, and policies at all levels.

In order to understand the status and the true sense of social justice and social justice leadership practices in the university, we need to see through historically disadvantaged groups' perspectives or spectacles. Consequently, the major purpose of the study was to investigate the perspectives of women and disables for social justice and social justice leadership. With the aim of this, the following basic questions were formulated:

1) How do women and persons with disabilities perceive social justice and social justice leadership in their university?

2) What are the challenges that women and disables are facing related to social justice and social justice leadership?

Thus, the investigation was meant to understand the lived experiences of participants' social justice and social justice leadership in the university. Besides, the results of the study attempted to expose problems and pinpointed possible feedbacks about the status and praxis of social justice and social justice leadership in the university. Thus, it is hoped that leaders may get information and see their leadership practices from women and disables' point of view. On top of this, it may help leaders craft and come up with different policies, rules and regulations which can benefit most importantly women and disables. In addition, this investigation may kindle the attention of top management team of the university and others to learn more about women and disable members of the university via this research.

\section{Context Description}

Similar to other higher education institutions across nation, the university under study has bestowed the responsibilities to run the instructional processes, conduct research activities, and initiate as well as innovations. It also aspires to be premier research university; and contribute substantially for the nation and beyond through high quality education, research and community services. The target university encompasses students, academic staffs, administrative staffs and other support staffs in permanent and temporary employments. All university members belong to different religious, ethnic and cultural backgrounds as they came from different parts of the country with different identities and characteristics. Thus, the university is expected to entertain these diversified groups, especially women and disables get equal treatment in every life endeavors and should act as models to other organizations. As an academic institution, it is also expected to reflect professionalism and rationalism. The university also consists of more than six campuses; and this study was delimited to mainly to its main campus.

Moreover, the university under study also consisted of 2449 academic staffs (male $=2008$; female $=441$ ), 50,575 students (male=35,266; female=15,309), 4512 administrative staffs (male $=1888$; female $=2624$ ) and 239 technical staffs (male $=181$; female $=58$ ). Totally, in the university under study, there are 7200 staffs including academic, administrative and technical staffs; which accounts 4077 (56.63\%) males and 3123(43.37\%) female staffs. Besides, it has 43,674 undergraduate students (male $=29,770$; female $=13,904), 5758$ Masters Students (male=4711; female=1047), $226 \mathrm{PhD}$ students (male=212; female=14), and 917 PGDT or postgraduate diploma in teaching students (male $=573$; female $=344$ ). In addition, female students' participations in percent for undergraduate, Masters, $\mathrm{PhD}$ and PGDT programs are $30.27 \%, 18.18 \%, 6.19 \%$ and $35.51 \%$ respectively. On top of this, the university under study consisted of 72 disable students (male $=50$; female $=22$ ). When split into programs, there are 52 undergraduate students (male $=36$; female $=16$ ), 20 Masters Students $($ male $=14$; female $=6$ ). Compared to total students participating in the university, disables account only $0.14 \%$; amongst these, male $=$ $0.14 \%$; female $=0.14 \%$ corresponding to the total male and female students. 
Furthermore, women at various leadership positions in the university accounted 18 females (at higher level=2; middle level $=5$ and lower level=11). But none of disable people were at leadership positions of any echelon.

\section{Methodology}

This study used a qualitative research design aimed at gaining in-depth knowledge about the topic under investigation (Denzin \& Lincoln, 2005; Marshall \& Rossman, 2006). More specifically, interpretive phenomenological research method was employed as it helps to describe and understand about the lived experiences and perceptions of homogeneous participants (Creswell, 2009). Thus, In-depth interview and focus group discussions were made to gather relevant data from the target population. Views of target groups were obtained through semi-structured interview as it helps to "get the subjects to freely express their thoughts around particular topics" (Bogdan \& Biklen (1998). Besides, both in-depth interviews and focus group discussions helped us to explore about social justice and social justice leadership from participants' point of views.

\subsection{Sample Size \& Sampling Technique}

Total sample participants of this research were 10 people. They were one visually impaired male lecturer, three women lecturers (two of them at leadership positions), one visually impaired male student and one physically disable female student. The focus group discussion was also made with four disable students (two visually impaired and two physically disable). To maintain the anonymity of participants, pseudonyms were used and hence; Selam- women lecturer one, Hana- women lecturer two, Emebet- women lecturer three, Eyob- visually impaired lecturer, Solomon- Visually impaired male student, and Tigist- physically disable female student. Thus, ten (10) participants were chosen using purposive sampling as it is the best way with such a small number of individuals for understanding perceptions, problems, needs, behaviors and contexts, which are the main justifications for a qualitative audience research (Bailey, 1994).

\subsection{Data Collection Procedures}

In this study, the data was collected by using the following procedure. First, purposely participants were selected and informed about the purpose of the study, and they were asked if they could participate in this research. Among the twelve participants who were asked to participate in the study, ten of them were willing and involved in the research. Then informed consent was made. It was promised that their identities would be kept in secret to ensure confidentiality. Second, interviews were planned to be held on an agreed-upon day, and participants were visited on that date. All interviews were recorded following participants permission and approximately, it took 30-40 minutes with each participant.

\subsection{Ethics and Trustworthiness}

Participants of the study were informed about the purpose of the study and requested to participate voluntarily. Prior to interviewing and focus group discussions, ethical approval was established by giving participants an informed consent. In addition, attempt was made to clarify participants about the confidentiality of the research to get in-depth answers with no hesitation. The interview locations were chosen carefully based on consensus reached to avoid the effect of power relations. Moreover, promise was made as their names will not be mentioned in any part of the study or shared with anyone else rather to use pseudonyms to maintain anonymity of participants. Furthermore, permission was asked to use a tape recorder by informing as it is only used not to miss important points of the discussion. Here, as interviewer we have played the role of facilitator and listener by asking questions and recording the answers without leading the participants towards any direction.

The participants were interviewed with semi-structured questions, which we ourselves developed based on ideas obtained from literatures. Then, we made efforts to ensure the content validity of the interview questions based on colleagues comment. However, this research have a problem of transferability to the total population; because, the samples of this study were only volunteers and few, which may not be fair representatives of the population. For this reason, the results have limitations. Hence, care should be taken to deduce any of the results to other population. Besides, the analyses and results are based on our interpretation as researchers.

\section{Findings and Analysis}

The finding and analysis of the study are presented in parallel. Thus, the study participants' perception on the essence of social justice, perceived understanding of university community towards women and disables, policies and strategies related to women and disables, practices of social justice and social justice leadership in the university and major challenges are presented. Therefore, this study was meant to pronounce the perception of women and disables for social justice and social justice leadership in the study context. 


\subsection{Perceptions on the Essence of Social Justice}

Participants have expressed their own perceptions and understandings about what social justice and social justice leadership meant to them. Some attempted to relate with equality; others with equity/fairness; and still others relate social justice and social justice leadership both with equality and equity or fairness issues. According to Selam, justice means fair distribution of resources. She added that fair resource distribution means proportional distribution of available resources according to the need, urgency and other criteria's. Justice is not merely equal distribution of resources. To elaborate her definition further she gave us an example, "Assume you have water to distribute to different animals. If you use equality criteria, you are being unfair. You cannot give a camel and a rat equal amount of water to ensure equality. The share of a rat may be a swimming pool for it (luxury)". From her explanation, we learnt that justice needs to be proportionate distribution of resources to the beneficiaries based on their need, urgency and other life challenges. Similarly, Molla (2013) argues, equity is beyond securing equal access to resources and opportunities. It includes reasonable adjustment to provide a differential treatment in accordance with the conditions and needs of the target groups for equality of outcomes.

On the other hand, Eyob also shared the idea of Lynch and Baker (2005), which states that social justice or justice is the key dimension to pursue equality of conditions so that people can pursue a good life, resources, respect and recognition, love, care and solidarity, power, working and learning. Moreover, Emebet understands social justice and social justice leadership as the process of creating "equal access and opportunities as well as empowering people to be self-reliant. As a result, people can make decisions of their own and determine their destiny". Furthermore, Solomon also explained that to define justice we need to look into the situations of different sectors and areas of life. He further explained that most of the facilities are made available targeting normal people without disabilities. He added that the education coverage in the country is good but there are only few schools with proper considerations and facilities for learners with disabilities. For instance, classroom buildings and the roads are not suitable even they can expose disable students to other types of disabilities. The technological advancements and outputs have also showed little considerations for disables in filling their gaps or limitations. Although he touched various issues and conditions, his explanation told us that to ensure social justice and social justice leadership, fair allocation of resources, proper services, societal support and other equality of conditions should be ensured.

Nussbaum (as cited in Coninck, Culp, \& Taylor, 2013) argues that in conceptualizing justice, the idea of capabilities remind one of the needs to make special efforts to address those unequal needs of people who begin from a position of social disadvantage. According to Molla (2013), social justice requires fair, not necessarily equal, access to opportunities and resources for all members of a society. It necessitates what Therborn (2006) calls 'compensatory capacitation', which leads to equality in capabilities and opportunities. This entails women and disables should get support based on their needs. Needs are different, and should be taken into considerations to ensure justice. Therefore, to realize social justice, fair and equal grounds should be in place for women and disables to fill in the deficiencies and gaps. Above all, despite their scope, research participants' awareness about and perception of social justice and social justice leadership were not so different from one another and not far-off from the definitions provided in literatures.

\subsection{Women and Disables' Perception of University Community Views towards Them}

People may develop different understandings about themselves and types of outlook that others have show to these people. Thus, interviewees were asked to explain their experiences related to other community members' views towards women and disables. Accordingly, Solomon explained that, "Most community members consider disabilities as cursed, especially illiterate people". And this was directly related to the research finding of JICA (2002) which states that in many parts of Ethiopia (both urban and rural), people view and associate disability (handicap) with spiritual evil and do not let disable persons to go out in public and exercise their rights. Because of such exclusions and undesirable community attitudes towards disabilities, a large proportion of people with disabilities are suffering from segregation and deprived of their rights. And this was also further explained in the study done by Barton (1996) and McDonnell (2003) (as cited in Lynch and Baker, 2005), because of undesirable community attitudes towards disability, people with disabilities are receiving non-standard and poorer quality education in separate schools, which ultimately results lower educational qualifications, fewer job opportunities, lack of job choice, lower pay and higher unemployment.

Moreover, Eyob added that, "Most disable individuals especially in rural areas are denied of education, kept at home, cannot create love and friendship or marriage, only a few like me escape such oppressions." He further explained that he became fortunate for education and other opportunities because he was adopted by a donor organization. Another interviewee, TIGIST, also explained that societies do not encourage people with 
disabilities to be strong by giving examples of successful individuals with disabilities. She said, "Mostly I felt hopeless, I usually see people with disabilities being mendicant and I felt many times that was my destiny". Therefore, lack of educational access, family and community supports made most people with disabilities segregated and forced them to lead impoverished living. And we have learnt from the responses obtained from Tigist that such undesirable outlooks towards disability are also sometimes reflected by some university community members albeit the magnitude differs.

Similarly, community views towards women are not also desirable and of supportive. In this regard, Shah (2010) explained that due to different reasons common to all societies seems to be a belief that male/female difference implies female association with domestic, nurturing, caring roles, which limit women in houses. Besides, Hana explained that, "Women are always disregarded, considered as incapable and incompetent. Women want to prove their capacity always. But because of inbuilt perception in community as women are incapable, once they get a chance for leadership positions, they should always prove themselves unlike men." This shows that yesterday's success of women does not guarantee for their future acceptances for better positions. Hana further elaborated that if a woman is successful being a department head, she should show herself better performances next day being a dean. In her perception, women are required to prove everyday to gain acceptance.

Furthermore, Selam also pronounced that, "Most of the time when women suggest ideas in meetings, nobody gives consideration/attention unless it is supported or approved in another men speaking next to them. This is a deep-rooted belief of the community that we currently experience." In favor of this, Alemu \& Asnake (2007) explained that, low status characterizes virtually every aspect of girls and women's lives. They further elaborated that different roles in the community make girls and women left with few opportunities to make and act on their own decisions. Consequently, these undesirable and harmful community perceptions discourage women not to participate actively in all walks of life similar to men. Even if women participate in leadership positions, she told us that women fear failure. If they fail, it is magnified on them. It seems failing is normal for men. Selam also added that "Everybody watches carefully our failure, they wait until we make mistakes, then they say you failed, they ridicule, you said we are equal to men, where is it? " Selam further explained "We compete and win leadership positions but most individuals think that we get positions by virtue of gender as an affirmative action not based on our capacity or competence." On top of this, Emebet on her own part also added that most of the time officials and the government prefer to take unnecessary credit by budgeting leadership positions as quota for women even when women are competent enough. This also not only discourages women but also violates their rights.

Furthermore, some higher officials do not have trust on women leaders. In this regard, Hana told us her experience. She was conducting a research with her friends sponsored by the University Research Directorate. The research office grants a budget for one research. She and her research colleagues took $60 \%$ of the budget according to the rule and made significant progress. Then she goes to research office for the remaining $40 \%$ with sufficient reasons and to provide progress reports about the research. However, she was asked, "have you made this truly? How could you made such progress with this short time etc.?" As she perceived, the intention was not to release the remaining budget. She explained, as this demands extra effort to secure her rights because she was simply perceived as incapable woman.

Our women interviewees emphasized that the perception of the community towards women was not so favorable; rather demoralizes women in leadership positions and forces them fail before trying the actual leadership tasks. Hana is a department head and told us her typical experience when she was at her office as, "People bring a letter to my office and said please give this to the department head" considering her as secretary. This is typical example of how much the society look down women and associate jobs (being secretary is only for women). Moreover, significant number of people understands affirmative action wrongly and perceive as women are incapable and inferior that is why affirmative action is given. This is congruent with Subrahmanian's idea (as cited in Molla,2013) that affirmative action policies for women may result in unintended negative consequences such as reinforcing the prejudice of incompetence and inferior status attached to women, which may eventually result in socio-psychological effects of negative self-perception and poor performance.

As the data obtained from our research participants, we have learnt that the perception of the university community towards women and disables are not favorable; and demands a lot of work to alter or correct such misconceptions and malpractices.

\subsection{Policies and Strategies Related to Women and Disables}

The Constitution of the Federal Democratic Republic of Ethiopia (FDRE, 1995) recognizes the degree of inequality between men and women, and it introduces affirmative action in economic spheres and social services, 
including education and training (Molla, 2013). The government declares equality for disables, minority and women via different legislations. In Ethiopia, both the Proclamation (FDRE, 2009) and the Strategic Framework for gender equality (MoE, 2004) do not explicitly recognize the specific nature of gender-related inequalities in the subsystem, and this undermines the effectiveness of the equity instruments of the policies. Supporting this, Selam argued the existence of different life challenges for women and men which the legislations did not consider. "People say you can win, the opportunity is there. Everybody preaches but in practice let alone fairness, there is no equality in the first place". She further explained that in "every sector in the name of democracy and affirmative action, attempts are being made to create equality without understanding the actual gap. She thinks that in this university, it is possible to help women to chair paid and unpaid committees". We must not make them sense they are leading because they are women; rather it is their right and they can do it.

According to Lynch and Baker (2005), women are marginalized in literature, art, science and history. They do not get equal attentions in class, their extra-curricular interests are defined as secondary to those of boys, and men disproportionately hold positions of authority. This neglect of women may be considered as cultural imperialism. Similar to this, Hana argued that the education system do not reflect equality of men and women because the curriculums and pedagogy are still male dominated. She raised the question, "Have you seen examples like pilot-Abebech (women name) in textbooks? Rather they associate women with secretary and lower office tasks".

People with disabilities also suffer injustice or discrimination, and continue to encounter barriers to their full participation in employment and in society more generally (Bogotch, 2014). In favor of this, Solomon argued that in Ethiopia there is no inclusive policy, which gives high emphasis to disable individuals compared to emphasis given to women. In the Ethiopian Constitution, the rights of disable people are only described in article 41 , section 4 . This article states that the government is responsible for the supply of rehabilitation services for disable persons and stated as:

"The State shall, within available means, allocate resources to provide rehabilitation and assistance to the physically and mentally disabled, the aged, and to children who are left without parents or guardian" (FDRE, 1995).

He further argued that, "Of course, Ethiopia is among the 83 countries who have signed the international convention but the implementation protocol is not yet signed. As a result, the issue of equality is almost ignored and officials use us only for political purposes". Solomon also added that disable individuals' account $15 \%$ to $17 \%$ of the total population of the country. There are five to eight million women and men in Ethiopia, or 7 to 10 per cent of the population with disabilities (UNICEF, 2009). It is estimated that people with disabilities are more than 7.3 million (MOLSA, 2010). However, their representations in employment and government higher positions are almost none. Solomon pointed out that the only disable person who holds higher government position is Mr. Asmelash (parliamentarian elect). According to his perception, women have better representations in parliament than disable individuals. Hence, he angrily uttered that, "No person speaks about/for us in House of People of Representatives". Solomon also recognized that the Amhara National Regional State gives better emphasis than the federal government. For example, if one individual competes for a job with a handicapped person; in federal system additional three marks are given to the person with disabilities; where as in Amhara Region if the disable candidate scores more than pass mark (usually 50\%), he/she will be granted the job, but still the implementation depends on individuals' or leaders will.

Furthermore, the federal government instructs all universities to employ more women as academic staffs. Despite all efforts to increase female staffs in public universities in the last 10 years, women account for only $11 \%$ of the academic staff in Ethiopia (MoE, 2011). However, nothing was said about disable individuals. Solomon further supported his argument with examples that; "My friend is visually impaired and he graduated last year (2015) scoring 3.8. He is jobless now at Tilili (a town about $70 \mathrm{~km}$ far from Bahir Dar City) but a woman, his classmate, scoring below 2.5 is now a graduate assistant lecturer at the University". Tigist also strengthened that, "Employers are usually reluctant to employ persons with any kind of disabilities". However, the proclamation concerning the Rights to Employment for Persons with Disabilities, No. 568/2008, requires avoiding discriminatory situations and providing appropriate working and training conditions for person with disability (MOLSA, 2010). Our disable interviewees and participants involved in focus group discussions explained unanimously that job and leadership opportunities are low and generally unfair.

From the interviews and focus group discussions, we learnt that regardless of policy issues and strategies set for women and disables, there are numerous hindrances that impede implementations and made those groups fail to benefit. As a result, there is a need for leaders make their doors open, have eyes and ears that enable them protect 
the rights of disable individuals. They should also develop positive attitude as people with disabilities can contribute important ideas and solutions to different problems in their own country.

\subsection{Practices of Social Justice and Social Justice Leadership in the University}

As Shah (2010) explained, gender is one of the few modes of differentiation that has social, cultural, political, and economic implications everywhere in the world. Besides, leadership concepts, theories and practices also evolve in this context in line to cultural \& belief systems. Therefore, the opportunities for women to practice leadership are almost none. Starting from the family to higher levels, women do not get fair opportunities to practice leadership. Women's social roles may restrict them from achieving the capabilities to lead the lives that they value and that lead to freedoms (Coninck, Culp \& Taylor, 2013). Thus, being a woman makes her to be disadvantaged; by being a mother she has many tasks; being a good wife required to take care of household activities including the kitchen and husbands need. These are also real facts on the ground that women experience in their lives.

During interviews, participants agreed that there are still males' dominance and chauvinistic thinking reflected in every sphere of life. Particularly, Hana questioned many thing as, "Who are classroom monitors? Who are chairpersons' in-group discussions in elementary and higher education? Who are leaders of different committees? Who are class representatives? Who are at the apex of every sector or organization in the country? Mostly men!" Surprisingly, most men and even women ourselves believe and recognize that when few leadership positions and professions are occupied by females, it is through affirmative action and the will of the government; nobody thinks that women deserved them. This also reminds the statement that Schmuck (as cited in Coleman, 2003), women who have achieved positions, and held predominantly by men have realized, consciously or unconsciously, that there are social roles, cultures and expectations governing the roles and lives of women. Consequently, they must become 'abnormal' women; they must transcend the social expectations of femaleness in order to aspire to socially prescribed roles of leadership. From the above responses and discussion, we came to realize that there are multi-faceted challenges that impede women not to exercise their rights and opportunities. And though many pro-women policies and strategies are in place, there are still long journeys to travel, and deep-rooted societal beliefs and taboos to stand against.

Specifically, in the study context, people at top leadership positions show good desire to participate women in leadership positions but still insignificant as our interviewees explained. In addition, the top managements were given directions by the government to incorporate more women in leadership positions. Currently, the maximum position held by women is vice president and there are deans and directors at various offices but still the proportion is not satisfactory. Selam told us that, in the college she belongs, she is the only women who represent women in academic commission meeting at college level. This forced women to think the university as if it is not willing and committed to hear women's voice; rather preferred to "see every action from their angle and men usually rule their voices". Hana also strengthened the idea by citing examples as, "No woman is in promotion committee; women loose promotion if they get pregnant." This shows that there must be someone to see their angle or shout on behalf of them being involved in different positions and committees.

Moreover, Selam explained that lack of women as good role models for others is also another problem for women not to be good and confident leaders. She added that, "There are rare successful women like the former university president but most lessons taken from women leaders are failures". She mentioned an example how one women dean in a certain college botched due to lack of experience. "A woman was assigned as a director despite no single experience in leadership [tasks]. She did not know the work, the [behavior of] the people and even the [type and nature of] bureaucracy. Soon after, she got frustrated; she could not accomplish her duties properly. Ultimately, she resigned from the leadership position". Of course, such practices are bad and frustrating for other women too who aspire to come to different leadership positions.

To point out unjust practices in the study context further, Hana told us that before three years ago, no position payment was allowed for department heads. During this time, almost more than half department heads in the university were women. She added that, "from college X, out of five positions, three were occupied by women". Soon after budget allocations for such positions, the game changed and everybody began shouting for headship positions followed by competency based policy which nobody was willing and claimed before. Moreover, the university management decided to make headship positions merit/competency based. Sadly, this also made most women to leave their headship positions for assistant professors and associate professors; whom most of them were men. All these were examples of unfair or injustices observed in my working organization, she argued.

Furthermore, participants also explained that information access is another challenge for women in their success of being a leader. They elaborated that, "Men unlike women are not responsible for household activities or 
children. This gives them to have leisure time, during this time they exchange information while drinking coffee or beer. The information they obtain helps to win micro-politics, and enhance their success at leadership position or office duties". Therefore, by virtue of being a woman and culture, women may not have access to information, even they may lose their rights due to lack of information. They added that, another challenge for women is sexual harassment. "Until we get into office, many things destruct our minds including positive and negative suggestions forwarded from men. It does not seem significant but it is a challenge 'usually emphasizes on ridiculing the efforts and status of women; which ultimately make women lose their confidence' and fail to fulfill leadership requirements". Actually, there is anti-harassment policy in the university but we do not report everything especially colleagues; but still it is a challenge for us to do our jobs, they explained.

On top of this, Selam explained another challenge for women to retain their leadership position during pregnancy. Women are forced to lose their leadership positions due to pregnancy. To elaborate further, "let me take what a woman dean suffered such kind of instance", she said. When she returned from maternity leave, another individual already took her deanship position. She added that, "It was not due to her capacity or end of her leadership term, it happened because she left her office due to maternity leave". And this was "quite unfair deed!" she angrily argued. Another sad story is, according to the university legislation, securing promotion demands two consecutive years of service and evaluation results. However, if a woman gets pregnant in the middle, she loses this opportunity. So, "where is fairness and social justice?" she asked angrily although we did not have answers to reply.

Interviewers interrogated both Selam and Hana to see themselves through the lens of applied critical leadership (Santamaria \& P Santamaria, 2011). In what ways do their identities (i.e., subjectivity, biases, assumptions, race, class, gender, and traditions) enhance their abilities to see other perspectives and therefore, provide effective leadership especially in ensuring social justice? They were specifically asked about what type of leader they are and the activities they are doing to ensure social justices. Because Selam did not have leadership role, she could not tell us what she has done to support women using her position but she explained that if there are opportunities, she aspires to make women's voice louder. However, Hana told us that, "As a department head, I am supporting women. For example, in practicum supervision, I assign women especially pregnant women in near places. I also fight against wrong grading systems committed due to sexual affiliation with instructors". She also added that she acts as a model for female students as she approaches students and listens to their complaints being department head. She concluded that, if there were many women in leadership position, it could likely that their voices would be heard more and benefits would be secured. This relates to the research finding of Odhiambo (2011) which stated that improving women's participation in leadership roles is an important part of the struggle to improve the freedom, rights and opportunities of all women worldwide.

With regards to social justice and social justice leadership related to disables Astin and Astin (as cited in Shields, 2004) explained that among the value ends of leadership should be to enhance equity and social justice that disable students desperately aspire to. In line to this, Eyob argued that, "Disable people never have a chance to experience leadership, especially visually impaired". He further explained that disable people in academic positions are only three in number and none of them are at leadership positions. Besides, these people are also treated in similar fashion like any other academic staffs in the university but nothing special. However, students are represented in different committees as leaders and members so that they are relatively in a good position to address their feelings and demands. Therefore, leaders of the university have a lot to do to ensure justice to individuals with disabilities since many of them are deprived of leadership positions and actions, as perceived by interviewees of this research.

Furthermore, Eyob recommended that disable individuals should be members of different committees in the university, not only academic staffs', students' should also be represented. Tigist, on her part, also commented officials at different positions in the university should make their doors open to disable students. From the interview data, we feel that conditions of disable students in the university should be investigated further so that unjust circumstances can be seen and get resolved collaboratively. In addition, there must be clear guideline and homemade policies that can address challenges of people with disabilities and should be communicated to students. As a result, this will improve their sense of belongingness and shows the university's concern for people with disabilities.

\subsection{Challenges to Ensure Social Justice and Social Justice Leadership in the University}

In our preceding discussions, a lot of issues were mentioned regarding the perceptions about the issues, community views towards women and disables, policies and strategies designed to address the needs of women and disables, and the actual social justice and social justice leadership practices in the study context. Besides, 
different types of challenges and lived experiences were also dealt with our interviewees. Under this point of discussion, major challenges that are impeding the lives of both women and disables will be looked at based on the responses of participants.

Educational institutions especially higher education institutions should take a lead in the fight against social injustice, and the values and praxis should reflect social justice. Besides, creating awareness, arming such skills and being pioneer in the agenda is expected from higher education institutions. In favor of this, Brown (2008) states that confronting issues of social justice, and arming people with the requisite knowledge and skills are both moral and legal imperatives that higher education institutions are required to do with passion and intelligence.

With regards to the concern of the legal system, in any governmental and nongovernmental organizations, women are eligible for three months of maternity leave by law. Besides, it is stated that the newly born baby has the right to feed breast for six months. To do so, women require time to go home early or come to office a bit late after feeding her child. However, the challenge happens on practices. To exercise such rights, there is no transport service made available for women because the transport service is meant for the majority most likely suitable for men not for a mother who feeds breast. Moreover, Hana angrily said that "women are required to get into first class early in the morning or they are required to fulfill office duties because men and women are assumed equal. For example, women are required to teach 12 credit hours work load per week, publish one article a year, and give one community service activity in a year". However, this legislation is equal to both women and men without considering any of the challenges that women experience merely by being a woman.

Similar to all universities in the country, there is Gender Office established to work on gender affairs, especially for the rights of women. According to Selam, Gender Office is perceived as a "lion without teeth". That is to say, the office is not granted commensurate authority and duties. Thus, it is difficult to ask about rights and complain with no one to fight for the rights and benefits of women. Let alone struggling for the rights of women, the office itself is not yet empowered, she further explained. Besides, Selam was asked to explain a bit further about the office, and elaborated that, "The office does not have a budget like other directorates or offices in the university. It devotes much of its time on other issues of the university and government agenda such as 1 to 5 grouping, Kaizen and other bureaucratic engagements". Therefore, based on the data obtained through interviews, Gender Office has nothing meaningful roles to ensure women's rights and benefits successfully. Besides, it is possible to understand that the office is not empowered and busy of other duties albeit further in-depth investigations are required to obtain more rigorous truth.

On top of this, even though the university is showing progress in all aspects of development, the attentions given to disable students are below expectations, as explained by interviewees and participants of focus-group discussions. They further described that with no context-based policies, rules and regulations accompanied by practical actions that enable respond and address to the questions and demands of disable people in the university, it becomes vain to talk of equity and issues of social justice. Eyob also explained that, "Other than the rights indicated in the constitution and other federal policy issues, the university has developed and implemented nothing special that favors academic staff members with disabilities". Academic staffs with disabilities are treated equally like other staffs in all responsibilities of the university. For instance, when research funds are granted, people with visual impairments are also given the same budget with no considerations of additional expenses such as fees for assistants involved in guiding, reading, administering questionnaires and other expenses for research activities. Besides, when there are competitions for leadership posts, scholarships, special trainings and other promotion related issues, the university does not have any special or homemade policies, rules or regulations that benefit us (i.e., people with disabilities) unless they are competent enough and excel other contestants.

Moreover, Eyob added that offices and classrooms for teaching are not comfortable for disables and they are similar to all others, and in this regard, "we are suffering a lot and nobody pays attention for this till now." With regard to the supports and empowerment activities for disable people, students get better support than academic staffs according to the views of Eyob. Solomon, on his part, explained the supports that disable students obtain from the university as, "We are given lots of supports by the university including battery, cassette, walkman (tape recorder), 'ken'(white stick), brail papers and monthly 200 birr pocket money. However, most equipment supports are given once up until we finish university education". According to his explanations, these equipments are given once assuming that they last all years of learning. Thus, the support is not enough because no substitution is given if some of them get damaged. Solomon also believes that the government allocates budget to universities based on number of students. This budget is used to buy projectors, chalk, white board, marker...etc which are not used and important for visually impaired students. Nevertheless, costs of these 
materials are included in cost sharing just like other students, which means students are going to pay for it after graduation. This is unfair or injustice according to him.

Furthermore, because of absence of clear directions on how to treat students with disabilities, the support disables get from teachers and other staffs depend on the personality and willingness of these groups. Emebet and other participants also agreed that sometimes personal willingness or kindness of leaders and others are reflected while providing supports and exercise the rights of women and disables. Besides, among issues that lack clear university direction include examination and pedagogical aspects. In this regard, Solomon argued that visually impaired students are taught Braille courses by normal (visually non-impaired) teachers whose examples and illustrations don't match, and PowerPoint slide presentations are not inclusive. On top of this, visually impaired students are also given similar exam types with 'normal' students and always forced to take examinations in a noisy places, seating outside the classroom. The time usually allotted for exams is also similar to 'normal' students which is unfair and injustice because visually impaired students entirely depend on the readers' (or students who read for them) ability and speed to read exams for blind students; whereas, students with no sight problems or 'normal' students usually maintain their pace based on the exam time allotted. In addition, the kind of teaching methodology most teachers use in the class is majority based, which means 'normal' benefit more than disable students especially visually impaired. The best example is when teachers use different diagrams to illustrate the lesson; students other than visually impaired ones benefit a lot.

Another major challenge for disable students was found to be the physical environment of the university. Though the physical environment of the university is beautiful and more convenient for most students, it is not suitable for students with disabilities, especially visually impaired. In relation to this, Solomon explained that, "Take the registrar; there are ducts around, which may create further disability". Focus group participants also angrily explained that classroom buildings, toilets, shower rooms, and dining halls are not suitable for disable students, especially for visually impaired and students with physical disabilities. These people are copping such difficulties with the help of other helpful students. Thus, from their explanations, we have learnt that considerations are required for infrastructure improvements and constructions.

On top of this, the interviewees have put their general evaluations and judgments with regard to the supports and encouragements given by the university as moderate for students and totally poor for academic staffs with disabilities. They also further asserted that this is not the issue of discrimination but negligence, ill-will and ignorance about the problems that disable people frequently face in the university. Besides, this is also the reflection of problems related to economic, political and socio-cultural developments of the country; and Eyob pointed out that, "I hope the situation will get better when we have better developments at national level". Yet, the university is not in a position to develop policy, rules and regulations that support and encourage disables, particularly academic staffs, and by large, the issue of social justice leadership in the university is "not known and not pronounced much", as it was told by interviewees of both students and academic staffs.

Above all, as participants argued, people with disabilities view social justice and social justice leadership not more than simple lip services though it is difficult to arrive at full-fledged judgments about the issues by interviewing few disables in the university.

\section{Conclusions}

It is true that social justice is creating equal and fair opportunities for human beings to lead a happy and better life regardless of who they are or conditions they are in. Therefore, leaders are responsible to ensure social justice for all. Social justice leaders are expected to set and apply policies and strategies that respond to the demands of all people regardless of their differences. Besides, historically marginalized people need to be given positions of authority to protect their rights and welfare of others under segregations.

The data obtained through interviews and focus group discussions showed that despite commendable efforts made by the university, there are still long ways to go in order to bring social justice and social justice leadership culture that provide fair and equitable services to all students and staffs. Consequently, everybody in the university should feel comfortable, belongingness, and should have equitable opportunities; and injustice deeds should be challenged. As pointed out by research participants, women and disables experience various types of unjust and discriminatory practices in their day-to-day practices. Some of these include: community views towards women and disables are not friendly and supportive; there are no tailored policies and strategies that respond to the needs of these groups, physical and material resources are inadequate and they are not in favor of people with disabilities, some staffs including leaders' attitudes towards women and disables are not supportive and inclusive. Moreover, the policies and strategies used to treat both women and disables were found to be unfair and injustice; such as in areas of recruitments for graduate assistant and lecturers in higher education 
institutions, and even in other public and non-public sectors. In this regard, compared to women, disables are given fewer attentions in that with minimal Grade Point Average (GPAs), women are selected to be graduate assistants in universities; whereas this policy doesn't work for disable graduates, even for those with better GPAs. Besides, there are lots of efforts being made and policy issues formulated as well as used so as to empower and benefit women not only in universities but also in all government and non-governmental sectors from national to local levels. And yet, public and non-public media are highly engaged in and busy of propagating life challenges of women and how to cope these challenges as well as practical actions to be taken. But none of these speak about and consider people with disabilities, as indicated in the data obtained from participants. Above all, data showed that both women and disables share many life challenges in common albeit the severity of the problem exceeds to people with disabilities in the study context.

Generally, as we have learned from our interviewees, social justice should be seen from different angles; education, social life, economy, health ... etc. We also learned, as we always have to ask; does the education system consider women and persons with disabilities in areas of access, curriculum, assessment system, pedagogy, instructional aid and others? How does the society within and outside of the university system perceive people with disabilities? Can they make love, marriage, and have children etc? Are university policies and strategies, if any, convenient for disables and women to promote and grow? Are there technological products that help people with disabilities freely explain their ideas substituting their disability? Most people with disabilities have low self-esteem, which needs the support and kind heart of the society. Are there attempts to avoid low self-esteem of people with disabilities due to their limitation?

\section{References}

Alemu, B., \& Asnake, M. (2007). Women's empowerment in Ethiopia: New solutions to ancient problems. Pathfinder International Ethiopia. Retrieved from www.pathfind.org

Bailey, K. D. (1994). Methods of social research (4th ed.). New York: The Free Press.

Bates, R. (2007). Educational administration and social justice. Education, citizenship and social justice, 1(2), 141-156. https://doi.org/10.1177/1746197906064676

Bogdan, R. C., \& Biklen, S. K. (2003). Qualitative research for education: An introduction to theories and methods (4th ed.). New York: Pearson Education.

Brown, K. M. (2008). Preparing future leaders for social justice, equity, and excellence: Bridging theory and practice through a transformative andragogy. USA: Christopher-Gordon Publishers, Inc.

Coleman, M. (2003). Gender and the orthodoxies of leadership. School Leadership \& Management, 3(23), 325 339. https://doi.org/10.1080/1363243032000112810

Coninck, J., Culp, J., \& Taylor, V. (2013). African perspectives on social justice. Uganda: Friedrich-Ebert-Stiftung.

Creswell, J. W. (2013). Qualitative inquiry and research design: Choosing among the five approaches (3rd ed). London, SAGE Publications.

Cribb, A., \& Gewirtz, S. (2003). Towards sociology of just practices: An analysis of plural conceptions of justice. In C. Vincent (Ed.), Social Justice, Education and Identity. London: Routledge Falmer.

Denzin, N. K., \& Lincoln, Y. S. (2005). The sage handbook of qualitative research (3rd ed.). Sage, Thousand Oak.

FDRE (Federal Democratic Republic of Ethiopia). (2009). Higher Education Proclamation (No. 650/2009) Addis Ababa: Federal Negarit Gazette.

FDRE [Federal Democratic Republic of Ethiopia]. (1995). The Constitution of the Federal Democratic Republic of Ethiopia (Proclamation No. 1/1995). Addis Ababa: Federal Negarit Gazette.

Federal Democratic Republic of Ethiopia Ministry of Labor and Social Affairs (MOLSA). (2010). Baseline study on the status of persons with disabilities and the influence of the African decade pronouncement in Ethiopia: Policies \& Program Implementation.

Freire, P. (1972). Pedagogy of the oppressed. Harmondsworth: Penguin.

Gale, T. (2000). Rethinking social justice in schools: How will we recognize it when we see it? International Journal of Inclusive Education, 4(3), 253-269. https://doi.org/10.1080/13603110050059178

Gale, T., \& Densmore, K. (2000). Just schooling: Exploration in the cultural politics of teaching. Birmingham, 
UK: Open University Press.

Hammersley, M. (n. d.). An outline of methodological approaches. Retrieved from www.tlrp.org/capacity/rm/wt/hammersley/hammersley4.html

JICA, (2002). Country profile on disability: Federal Democratic Republic of Ethiopia. Japan International Cooperation Agency Planning and Evaluation Department. Retrieved from www.worldbank.org

Lynch, K., \& Baker, J. (2005). Equality in education: An equality of condition perspective. Theory and Research in Education. Sage Publications. https://doi.org/10.1177/1477878505053298

Mackenzie, N., \& Knipe, S. (2006). Research dilemmas: Paradigms, methods and methodology. Issues in Educational Research, 16(2), 193-205. Retrieved from www.iier.org.au/iier16/mackenzie.html

Marshall, C., \& Rosman, B. G. (2006). Designing qualitative research (4th ed.). Sage, Thousand Oak.

Molla, T. (2013). Higher education policy reform in Ethiopia: The representation of the problem of gender inequality. Higher Education Policy, 26, 193-215. https://doi.org/10.1057/hep.2012.25

Moule, J. (2005). Implementing a social justice perspective in teacher education: Invisible burden for faculty of color. Teacher Education Quarterly, 23-40.

Odhiambo, G. (2011). Women and higher education leadership in Kenya: a critical analysis. Journal of Higher Education Policy and Management, (33), 667-678. https://doi.org/10.1080/1360080X.2011.621192

Saeeda, J. A. (2010). Rethinking educational leadership: exploring the impact of cultural and belief systems. International Journal of Leadership in Education, 13(1), 27-44. https://doi.org/10.1080/13603120903244879

SantamarIa \& P SantamarIa. (2011). Applied critical leadership: Choosing change. New York and London. Routledge Taylor \& Francis Group.

Scherlen, A., \& Robinson, M. (2008). Open access to criminal justice scholarship: A matter of social justice. Journal of Criminal Justice Education, 19(1), 54-74. https://doi.org/10.1080/10511250801892961

Shields, C. (2004). Dialogic leadership for social justice: Overcoming pathologies of silence. Educational Administration Quarterly, 40(1), 109-132. https://doi.org/10.1177/0013161X03258963

Sturman, A. (1997). Social Justice in Education. The Australian Council of Educational Research. Melbourne: vol. 40 .

Theoharis, G. (2004). Toward a theory of social justice leadership: Paper presented at the University of Council of Educational Administration, UCEA Conference Proceedings, Thompson, D. \& Crompton, F. (editors), Kansas City, OM.

Tsegay, T. S. (2013). Some Ethiopian women leaders' perceptions about their leadership. Advancing Women in Leadership, 33, 75-86. Retrieved from www.advancingwomen.com/awl/awl_wordpress/

UNICEF. (2009). Ethiopia Disability Programme. Factsheet. Retrieved from: www.unicef.org/ethiopia/ET_Disability_fact_sheet_Nov_06.pdf

\section{Copyrights}

Copyright for this article is retained by the author(s), with first publication rights granted to the journal.

This is an open-access article distributed under the terms and conditions of the Creative Commons Attribution license (http://creativecommons.org/licenses/by/4.0/). 